\title{
Dicere Non Nocere: Public Disclosure of Identifiable Patient Information by Health Professionals on Social Media
}

\author{
Matthew S. Katz MD, ${ }^{1}$ Wasim Ahmed PhD, 2 Thomas G. Gutheil MD, ${ }^{3,4}$ Reshma Jagsi \\ MD DPhil ${ }^{5}$ \\ ${ }^{1}$ Department of Radiation Medicine, Lowell General Hospital, Lowell, MA \\ 2 Newcastle University Business School, Newcastle University, Newcastle Upon \\ Tyne, United Kingdom \\ ${ }^{3}$ Department of Psychiatry, Beth Israel Deaconess Medical Center, Boston MA \\ ${ }^{4}$ Massachusetts Mental Health Center, Harvard Medical School, Boston, MA \\ ${ }^{5}$ Center for Bioethics and Social Science in Medicine, University of Michigan, Ann \\ Arbor, MI
}

\section{Corresponding Author:}

Matthew S. Katz, M.D., Department of Radiation Medicine, Lowell General Hospital, 295 Varnum Avenue, Lowell, MA.

Telephone: (978) 937-6274

Facsimile: (978) 937-6835

Email: $\quad$ Matthew.Katz@lowellgeneral.org

Twitter: @subatomicdoc

\section{Disclosures:}

Dr. Katz reports common stock ownership in Dr. Reddy's Laboratories, Healthcare Services Group, Mazor Robotics, and U.S. Physical Therapy.

Dr. Ahmed has nothing to disclose.

Dr. Gutheil has nothing to disclose.

Dr. Jagsi reports stock options as compensation for her advisory board role for Equity Quotient, a company that evaluates culture in health care companies. She has received personal fees from Amgen and Vizient for consulting, fees from the Greenwall Foundation for service as a grant reviewer, and grants for unrelated work from the National Institutes of Health, the Doris Duke Foundation, the Greenwall Foundation, the Susan G. Komen Foundation, and Blue Cross Blue Shield of Michigan for the Michigan Radiation Oncology Quality Consortium. 
medRxiv preprint doi: https://doi.org/10.1101/2020.03.05.20031526; this version posted March 6, 2020. The copyright holder for this preprint (which was not certified by peer review) is the author/funder, who has granted medRxiv a license to display the preprint in perpetuity.

\begin{abstract}
Background Respecting patient privacy and confidentiality is critical for doctorpatient relationships and public trust in medical professionals. The frequency of potentially identifiable disclosures online during periods of active engagement is unknown. Our aim was to quantify potentially identifiable content shared by physicians and other health care providers on social media using the hashtag \#ShareAStoryInOneTweet.
\end{abstract}

Methods We used Symplur Signals software to access Twitter's API and searched for tweets including the hashtag. We identified 1206 tweets by doctors, nurses, and other health professionals out of 43,374 tweets shared May 1-31, 2018. We evaluated tweet content in January 2019, eight months after the study period. To determine the incidence of sharing names or potentially identifiable information about patients, we performed a content analysis of the 754 tweets in which tweets disclosed information about others. We also evaluated whether participants raised concerns about privacy breaches and estimated the frequency of deleted tweets. We used dual, blinded coding for a $10 \%$ sample to estimate inter-coder reliability for potential identifiability of tweet content using Cohen's kappa statistic.

Results 656 participants, including 486 doctors (74.1\%) and 98 nurses (14.9\%), shared 754 tweets disclosing information about others rather than themselves. Professional participants sharing stories about patient care disclosed the time frame in $95(12.6 \%)$ and included patient names in 15 (2.0\%) of tweets. We estimated that friends or families could likely identify the clinical scenario described in $32.1 \%$ of the 754 tweets. Among 348 tweets about potentially living patients, we estimated 
$162(46.6 \%)$ were likely identifiable by patients. Inter-coder reliability in rating the potential identifiability demonstrated $86.8 \%$ agreement, with a Cohen's Kappa of 0.8 suggesting substantial agreement Of the 1206 tweets we identified, 78 (6.5\%) had been deleted on the website but were still viewable in the analytics software dataset.

Conclusions During periods of active sharing online, nurses, physicians, and other health professionals may sometimes share more information than patients or families might expect. More study is needed to determine whether similar events arise frequently online and to understand how to best ensure that patients' rights are adequately respected. 
medRxiv preprint doi: https://doi.org/10.1101/2020.03.05.20031526; this version posted March 6, 2020. The copyright holder for this preprint

(which was not certified by peer review) is the author/funder, who has granted medRxiv a license to display the preprint in perpetuity.

All rights reserved. No reuse allowed without permission.

\section{Introduction}

Physicians, nurses, and other health professionals remain among the most trusted professions in the U.S. because of their commitment to the well being of others, making them a source of trusted health information and guidance. ${ }^{1}$ Surveys demonstrate the high trust of the U.S. public in health care professionals (HCPs) with even higher levels of trust in other countries. ${ }^{1,-3}$ Still recited by many medical students as they become physicians, the Hippocratic oath reflects the fundamental importance of patient privacy as a critical element of the doctor-patient relationship and precondition for the trust of the public. In the U.S., the Health Insurance Portability and Accountability Act (HIPAA) requires de-identification to avoid sharing protected health information. ${ }^{4}$

Fulfilling physicians' obligations to protect the well-being and privacy of their patients is complicated in the age of the internet. Internet culture is very different from that of the medical profession, creating potential ethical problems with appropriate boundaries and privacy that did not exist when physicians interacted exclusively offline. In order to maintain the trust of the public and that of individual patients, physicians increasingly need to understand the limits and risks of disclosure of certain types of information online. Although concerns about unprofessional medical student and resident behavior online have been articulated before, ${ }^{5,6}$ the ethical risks of public disclosure, when narrative medicine intersects with social media, remain poorly defined. ${ }^{7,8}$ 
In May 2018, thousands of individuals_-including many health care professionalsshared health-related stories on Twitter using the hashtag

\#ShareAStoryIn0neTweet in response to one physician's spontaneous tweet about a patient story, with this hashtag included. Certain tweets included potentially identifiable information that could be considered a breach of confidence if disclosed without patient consent, risking harm to patients, physician's careers, and public trust in the profession.

A July 2018 article highlighted the importance of sharing stories but did not address the potential risks of sharing online. ${ }^{9}$ Over time, some 'viral' tweets were deleted, raising further concerns that the easy platform for disclosure might have led to posts that authors subsequently regretted. A notable example of a popular post (altered to avoid identification) was retweeted 13,491 times and liked by 55,994 people before being deleted:

"I delivered a baby very underweight, weighing two pounds. They said he did not have a chance. I remained with him for a couple of days. Nine years later, he played his first football game last week."

Hashtags can make online content searchable and discoverable online, regardless of time since publication. The American Medical Association, Massachusetts Medical Society, and other organizations advise physicians to report unprofessional social media use. ${ }^{10,11}$ What constitutes unprofessional behavior on social media is not clearly defined. To advance a common understanding and to facilitate subsequent 
medRxiv preprint doi: https://doi.org/10.1101/2020.03.05.20031526; this version posted March 6, 2020. The copyright holder for this preprint

(which was not certified by peer review) is the author/funder, who has granted medRxiv a license to display the preprint in perpetuity.

All rights reserved. No reuse allowed without permission.

discussion within the profession about what is appropriate, we sought to describe participation of physicians and other health professionals in this event, the reach of their postings, and the prevalence of potentially identifiable disclosures about patients.

\section{Methods}

\section{Cohort Definition}

Because all information about the published content were publicly accessible, Lowell General Hospital approved this study as IRB exempt. To evaluate content in the \#ShareAStoryIn0neTweet phenomenon, we used Symplur Signals, a proprietary healthcare-focused database and analytics program collecting data on Twitter using its Enterprise application program interface. ${ }^{12}$ The first tweet with the hashtag occurred May 4, 2018. From May 1, 2018 through December 31, 2018, we identified 45,040 tweets including the hashtag \#ShareAStoryIn0neTweet. We focused on the 43,374 tweets shared in the month of May 12018 00:00:00 to June 1 00:00:00 Eastern Standard Time. We conducted our analysis in January 2019, eight months after the study period.

We used the software program's classification to identify doctors, patients, and other healthcare stakeholders (e.g. caregivers, pharmaceutical firms, academic or research organizations) based upon public self-identification in their Twitter profiles. $^{13}$ For May 2018, we identified 4,871 tweets with the hashtag shared by doctors and other healthcare providers, of which 1,206 were unique (the remainder represented "retweeting" of prior postings). 
We reviewed the 1,206 tweets by reading text provided within the dataset and then evaluating the URL and each account's public profile on Twitter's website as of March 2019. We excluded those from students misclassified as healthcare providers (1.3\%) (e.g. listing 'future doctor' in profile), blocked accounts $(0.3 \%)$, or if no relevant content was posted with the hashtag (1.2\%), leaving a total of 1,172 tweets shared by physicians, nurses, or other health professionals [Figure 1]. We excluded 26 "retweets" in which the authors used the hashtag to share someone else's disclosure rather than their own and 127 that included the author's own illness experiences rather than those of others. We also excluded 78 tweets $(6.5 \%)$ with content found in the dataset but deleted from Twitter when evaluated on the website.

We examined characteristics of the 656 health professionals sharing these tweets, using information publicly available in their online profiles, including profession, gender, and country. For physicians, we also categorized by specialty as described in their profiles, or unknown if not stated. More detailed content analysis focused upon the 754 tweets (62.5\%) in which the healthcare professional shared the illness or clinical experience of someone other than the tweet author.

We also evaluated the 187 tweets commenting upon the hashtag-related phenomenon or recommending participation to others separately. We analyzed tweets individually rather than as content threads. 


\section{Measures}

To assess the magnitude of hashtag use, we evaluated total number of tweets. We also evaluated the number of total participants, focusing upon physician, nurse, and other HCP use during May 2018. We calculated tweets per hour, number of tweets, and use of images both in aggregate and by healthcare stakeholder categories. In order to capture hourly tweet activity rates, we restricted the time frame to the first two weeks starting May $4^{\text {th }}$ to focus on the 'viral' period of sharing. We evaluated the potential reach of the tweets using the software's definition of impressions, calculating each tweet author's follower count at the time of each tweet's publication online (e.g. a doctor posting while having 500 followers $=500$ impressions).

For the content analysis, for each tweet we coded several measures: the tweet author's role in the other person's clinical care; whether the patient died or was actively dying; whether the author helped save the other person's life; inclusion of patient name; inclusion of a clinical image; and inclusion of a specific age. Based upon the tweet, we categorized the time frame of the event(s) described as within the past year, 1-2 years ago, 2-5 years ago, >5 years, or unknown.

To assess whether a either a patient or her/his family or friends would be able to identify the clinical scenario described in each tweet, we categorized both questions broadly as likely (defined as "more likely than not to be identifiable") or not (not meeting that threshold). One author (MK) assessed all tweets; a second author (WA) 
coded a 10\% sample independently and inter-coder reliability was assessed with ReCal software. ${ }^{14}$ The two authors then reached consensus on discrepancies and used this exercise to identify any areas where the first coder might systematically have erred.

Because the tweets could be discoverable in malpractice or tort suits, we also analyzed whether the author made comments with a negative opinion about the patient or family, or if s/he acknowledged that a medical error occurred. We also assessed whether information was shared about vulnerable patients, as defined by the U.S. Department of Health and Human Services. ${ }^{15}$

We separately evaluated the 187 tweets commenting upon the hashtag to determine whether the authors had a favorable or unfavorable opinion of the viral sharing, or if they invited others to share stories or to participate. We also identified whether these tweets expressed any concern about privacy breaches.

\section{Statistical Analysis}

Symplur provided data for overall activity and frequencies for stakeholder participation. For the detailed content analysis we calculated frequencies, median and mean endpoints with Microsoft Excel for Mac 2011 version 14.7.2. We used Cohen's kappa statistic to measure inter-rater reliability. ${ }^{16}$

\section{Results}


medRxiv preprint doi: https://doi.org/10.1101/2020.03.05.20031526; this version posted March 6, 2020. The copyright holder for this preprint (which was not certified by peer review) is the author/funder, who has granted medRxiv a license to display the preprint in perpetuity. All rights reserved. No reuse allowed without permission.

Tweet Volume and Participants

For May 2018, we identified 31,690 participants posting tweets with the hashtag, with a potential of 106.5 million views. A total of 1725 individuals self-identifying as doctors and 861 as other healthcare providers shared tweets with the hashtag, representing $5.3 \%$ and $2.6 \%$ of the total participants, respectively. At its peak activity for sharing, participants in this phenomenon tweeted 1274 times/hour

\section{[Figure 2].}

\section{Participants and Tweets with Disclosures about Others}

The characteristics of the 656 health professionals sharing tweets with disclosures about others are presented in Table 1. Of the participants, 384 (58.5\%) were female. Physicians constituted the largest proportion of the tweeters (74.1\%), with nurses representing a minority (14.9\%). Among physicians, emergency medicine, family medicine/general practice, and hematology-oncology were the specialties most frequently represented. Most of the 656 participants were in the United States (52.9\%), followed by Canada (15.1\%) and the United Kingdom (12.5\%).

Among the 754 tweets focused upon the illness experience of someone other than the author, the majority (87.4\%) involved the sharing of stories about direct patient care, rather than the author's role as a family caregiver or in another role [Table2]. In $13.6 \%$ of cases, tweets included a specific time frame. The patient's age was included in 163 (21.6\%) of these tweets, and patient name was included in 15 (2.0\%). Eleven tweets (1.5\%) shared a clinical image. 152 tweets (20.2\%) shared information about people in a vulnerable category. Two posts $(0.3 \%)$ mentioned 
patient consent to share within that tweet, one explicitly and one inferred from past patient agreement to share a specific story. Based upon the number of likes, a minimum of 154,900 accounts viewed these 754 tweets.

Nearly half of the tweets (44.7\%) described a clinical scenario involving death or dying. Comments disclosing medical errors or expressing a negative opinion about the patient or family were rare $(0.8 \%$ and $0.5 \%$, respectively).

Inter-coder reliability in rating the identifiability by patients or by family both demonstrated $86.8 \%$ agreement, with a Cohen's Kappa of 0.8 suggesting substantial agreement. In evaluating the potential for unintended identification of the clinical scenario, we estimated that almost one third (32.1\%) of families or friends would likely find the content in the tweet identifiable. Among patients who were potentially still living, we estimated that nearly half (46.6\%) likely could identify the information shared about themselves. Of the 162 tweets we estimated patients would likely be able to identify, we estimated that 81 (50\%) would likely be identifiable by families and friends. The 754 tweets by participants received a median of two retweets (range: 0-19,959) and 16 likes (range: 0-56,735).

Tweets Relating to the Hashtag

Of the 187 tweets actively part of the conversations without disclosures, 173 (92.5\%) made some commentary. Six (3.2\%) raised concerns about privacy or identifiable information in the tweets with disclosures, and one involved another 
medRxiv preprint doi: https://doi.org/10.1101/2020.03.05.20031526; this version posted March 6, 2020. The copyright holder for this preprint

(which was not certified by peer review) is the author/funder, who has granted medRxiv a license to display the preprint in perpetuity.

All rights reserved. No reuse allowed without permission.

critical comment; the remaining 167 were neutral or favorable. A total of 42 tweets $(22.5 \%)$ invited others to read the hashtag's stream or contribute to it.

\section{Discussion}

In this retrospective study, we describe a physician-initiated event sharing healthrelated stories and information on Twitter, quantifying the global participation of healthcare professionals and the type of content shared. Their tweeted stories became widely shared, attracting media attention and disseminating the information widely. Almost none explicitly appear to confirm consent to share information publicly on a popular social network. Nurses, physicians, and other professionals commenting using the hashtag were more likely to express support for the event and encourage others to participate than they were to raise concerns about patient privacy breaches. However, recent research suggests that $12 \%$ of patients may have less trust in physicians describing patient stories on social media, even if shared respectfully. ${ }^{17}$

We observed a relatively high incidence of sharing stories including details that might make them potentially identifiable to patients themselves and even to families and friends in a setting that involved a large number of healthcare professionals compared to prior studies. Early in the use of social media, most U.S. state medical boards received at least one episode of online professionalism violations reported for disciplinary action, including violations of patient confidentiality. ${ }^{18}$ Surveys of medical students and physicians suggest the prevalence of unprofessional behavior among medical students is infrequent. ${ }^{19,20}$ Our study indicates that in some 
circumstances healthcare professionals may share more information publicly than the public might expect. Privacy breaches risk potential negative effects for relationships with their patients, for professional disciplinary actions or torts, and for erosion of public trust.

Our findings differ from prior studies of online medical professionalism at least partly because we analyzed in detail a specific event focused upon health-related disclosures. There is no indication this episode was planned, but the incidence of similar episodes is unknown. But it is not an isolated event; for example, another prominent example involves physicians opposing gun violence, who used the hashtag \#ThisIsOurLane on Twitter in November 2018. ${ }^{21}$ Physicians focused on policy issues, but some may have failed to recognize privacy concerns, publishing tweets with photographs similar in nature to prior social media content that has in certain other cases resulted in professional termination..$^{22,23}$ Social media studies publishing tweets often permit reverse identification of the authors, ${ }^{24}$ and a survey suggests that most 'participants' are somewhat or very uncomfortable if their tweets were to be quoted in a published research paper. ${ }^{25}$ In our study, we found that $6.5 \%$ of tweets archived in the software's archived dataset were in fact deleted by healthcare professionals, indicating that some did not want their tweets to remain publicly visible. Even if deleted online, publishing tweets in journals enhances permanence and discoverability.

Most research evaluating online disclosures focus on the privacy paradox, in which people value their privacy but still share their own information. Surveys indicate 
people may value short-term social rewards of self-disclosure online more than long-term privacy concerns, ${ }^{26}$ and high social capital of social network users is associated with increased self-disclosures over time. ${ }^{27}$ For people disclosing information about others, the research is more limited, but opinion leadership and female gender are linked to less concern about others' privacy, ${ }^{28}$ consistent with the findings of our study. Healthcare professionals may be prone to these same tendencies, despite their training and education to maintain privacy. Generational differences concerns about privacy online may also play a role, ${ }^{29}$ but we could not assess that possibility in this study.

Based upon the temporal pattern of sharing, this hashtag-related event may be less similar to narrative medicine and writing than to a brief episode of social contagion, in which viral sharing of content or emotions online may occur and involve more than simple, conscious risk/reward tradeoffs. ${ }^{30,31}$ Unlike traditional peer-reviewed publication of a medical story in narrative medicine, tweeting occurs quickly and does not permit editing. The observation that $6.5 \%$ chose later to delete their contributions may suggest that some health care professionals who participated in the experience may have later viewed their behavior as a temporary lapse in judgment.

Another contributing factor may be a knowledge gap for physicians and other healthcare professionals on how to behave online. While many recognize the importance of online professionalism, curricula for formal medical education training are only beginning to emerge and remain uncommon. ${ }^{32-4}$ In this study, no 
medRxiv preprint doi: https://doi.org/10.1101/2020.03.05.20031526; this version posted March 6, 2020. The copyright holder for this preprint (which was not certified by peer review) is the author/funder, who has granted medRxiv a license to display the preprint in perpetuity.

All rights reserved. No reuse allowed without permission.

tweet with met criteria for justifiable release of identifiable information without consent, and the ethical obligation to maintain confidentiality does not end with a patient's death. ${ }^{35}$ The digital medium does not avoid the potential that disclosures about patients risk breaching confidentiality, undermining trust within that therapeutic relationship as well as public trust in the medical profession. Our findings suggest a potential need for evidence-based training in ethical digital communications skills for the undergraduate, graduate and continuing medical education. Professional societies could create resources that allow social media authors to document having obtained consent, so that disclosing identifiable patient information without consent does not inadvertently become normalized.

\section{Limitations}

Our study has several limitations. First, we studied a very specific event that may occur during very active periods of online engagement but likely overestimates the general incidence of online behaviors that could in some cases constitute violations of medical professionalism. Second, we could not assess the number of people actually seeing these tweets, resulting in a wide range since we could only measure the number of likes and potential reach. Third, we only analyzed tweets from accounts that the software identified as healthcare professionals. Our evaluation of all tweets in the cohort confirms the software rarely misclassified non-professionals into this group, but we did not evaluate any other participants in the event to determine if we could identify more participating healthcare professionals not categorized as doctors or nurses by the software, which could decrease or increase the incidence of potential privacy breaches. Fourth, by analyzing only tweets with 
the hashtag, we potentially underestimated the frequency of others expressing concern about patient privacy. Fifth, given the brevity inherent to the medium of Twitter, it is possible that some authors did indeed have formal documentation of patients' consent to share their stories but that there was insufficient room to include due to character limits in each post. Finally, our assessment of identifiability might differ from others, and we cannot exclude the possibility that some physicians and nurses tweeting what seemingly identifiable stories consciously changed important details to de-identify. It was beyond the scope of this study to confirm whether any harm occurred.

Despite these limitations, our study clearly shows that internet-based sharing raises potential pitfalls for medical professionalism. The Internet provides nurses, physicians, and other professionals the opportunity to help or harm others on a global scale. Although Internet culture may favor maximizing transparency, it can also pose the risk of directly contradicting health professionals' fiduciary duty: first, do no harm, including in what we say.

\section{Conclusion}

We identified an episode with a high incidence of potential privacy breaches online compared to previous reports. More research is essential to confirm our findings and determine how to ensure physicians, nurses, and other professionals adapt their behavior to maintain medical professionalism in the digital age. 
Author Contributions: $\quad$ Dr. Katz had full access to all of the data in the study and takes responsibility for the integrity of the data and the accuracy of the data analysis. All estimates and analyses in this article are by the authors.

Concept and design: Ahmed, Gutheil, Jagsi, Katz

Acquisition, analysis, or interpretation of data: Ahmed, Gutheil, Jagsi, Katz

Drafting of the manuscript: Katz, Jagsi

Critical revision of the manuscript: Ahmed, Gutheil, Jagsi, Katz

Statistical analysis: Katz

Obtained funding: Katz

Administrative, technical, or material support: Katz

Supervision: Gutheil, Jagsi 
medRxiv preprint doi: https://doi.org/10.1101/2020.03.05.20031526; this version posted March 6, 2020. The copyright holder for this preprint (which was not certified by peer review) is the author/funder, who has granted medRxiv a license to display the preprint in perpetuity.

All rights reserved. No reuse allowed without permission.

\section{References}

1. Brenan M. Nurses again outpace other professions for honesty, ethics. Gallup.com 12/20/18

2. Blendon RJ, Benson JM, Hero JO. Public trust in physicians - U.S. medicine in international perspective. New EnglJ Med. 2014;371(17):1570-1572

3. Huang EC, Pu C, Chou Y-J, et al. Public trust in physicians - health care commodification as a possible deteriorating factor: a cross-sectional analysis of 23 countries. Inquiry. 2018;55:46958018759174

4. U.S. Department of Health and Human Services, Washington, DC: Guidance regarding methods for de-identification of protected health information in accordance with the Health Insurance Portability and Accountability Act. (https://www.hhs.gov/hipaa/for-professionals/privacy/special-topics/deidentification/index.html)

5. Thompson LA, Dawson K, Ferdig R, et al. The intersection on online social networking with medical professionalism. J Gen Intern Med. 2008;23(7):954957

6. Chretien KC, Greysen SR, Chretien JP, Kind T. Online posting of unprofessional content by medical students. JAMA. 2009;302(12):1309-1315

7. Ofri D. The passion and the peril: storytelling in medicine. Acad Med. 2015;90(8):1005-1006

8. Wells DM, Lehavot K, Isaac ML. Sounding off on social media: the ethics of patient storytelling in the modern era. Acad Med. 2015;90(8):1015-1019

9. Rosenbaum L. Twitter tailwinds - little capsules of gratitude. New Engl J Med. 2018;379(3):209-211 
medRxiv preprint doi: https://doi.org/10.1101/2020.03.05.20031526; this version posted March 6, 2020. The copyright holder for this preprint (which was not certified by peer review) is the author/funder, who has granted medRxiv a license to display the preprint in perpetuity. All rights reserved. No reuse allowed without permission.

10. Professionalism in the Use of Social Media. Chicago, IL: American Medical Association. Accessed April 2019. (https://www.ama-assn.org/deliveringcare/ethics/professionalism-use-social-media)

11. MMS Physicians' Guide to Social Media. Waltham, MA: Massachusetts Medical Society Communications Committee, March 2016. (http://www.massmed.org/Governance-and-Leadership/Committees,-TaskForces-and-Sections/MMS-Physicians--Guide-to-Social-Media-(pdf)/)

12. Symplur API. https://www.symplur.com/product/symplur-api/

Authentication documentation at https://docs.symplur.com/reference\#authentication

13. Utengen A. Healthcare Stakeholder Segmentation. https://help.symplur.com/en/articles/103684-healthcare-stakeholdersegmentation. Accessed January 15, 2020

14. Freelon D. ReCal: Intercoder reliability calculation as a web service. Int J Internet Science. 2010;5(1):20-33

15. Office if Human Research Protections, https://www.hhs.gov/ohrp/regulations-and-policy/guidance/vulnerablepopulations/index.html. Accessed April 2, 2019

16. McHugh M. Interrater reliability: the kappa statistic. Biochemia medica. 2012;22(3):276-282

17. Fatollah JJ, Colbert JA, Agarwal P, et al. The impact of physician social media behavior on patient trust. AJOB Empir Bioeth 2019;30:1-6

18. Greysen SR, Chretien KC, Kind T, Young A, Gross CP. Physician violations of online professionalism and disciplinary actions: a national survey of state medical boards. JAMA. 2012;307(11):1141-1142

19. Thompson LA, Black E, Duff WP, et al. Protected health information on social networking sites: ethical and legal considerations. J Med Internet Res. 2011;13(1):e8

20. Brynolf A, Johansson S, Appelgren E, Lynoe N, Edstedt Bonamy AK. Virtual colleagues, virtually colleagues - physicians' use of Twitter: a populationbased observational study. BMJ Open. 2013;3(7):e002988 
medRxiv preprint doi: https://doi.org/10.1101/2020.03.05.20031526; this version posted March 6, 2020. The copyright holder for this preprint (which was not certified by peer review) is the author/funder, who has granted medRxiv a license to display the preprint in perpetuity.

All rights reserved. No reuse allowed without permission.

21. Ranney ML, Betz ME, Dark C. \#ThisIsOurLane - Firearm safety as health care's highway. New Engl J Med. 2019;380(5):405-407

22. Danzig C. ER Doc forgets patient information is private, gets fired for Facebook overshare. https://abovethelaw.com/2011/04/er-doc-forgetspatient-info-is-private-gets-fired-for-facebook-overshare/

23. Li DK. 'New York Med' nurse fired for 'insensitive' Instagram shot. https://nypost.com/2014/07/08/new-york-med-nurse-katie-duke-firedfor-insensitive-instagram-shot/

24. Ayers JW, Caputi TL, Nebeker C, Dredze M. Don't quote me: reverse identification of research participants in social media studies. npj Digital Medicine. 2018;1:30, doi:10.1038/s41746-018-0036-2

25. Fiesler C, Proferes N. "Participant" perceptions of Twitter research ethics. Social Media + Society. 2018;4(1):1-14

26. Hallam C, Zanella G. Online self-disclosure: the privacy paradox explained as a temporally discounted balance between concerns and rewards. Computers Human Behavior. 2017;68:217-227

27. Trepte $S$, Reinecke L. The reciprocal effects of social network site use and the disposition for self-disclosure: a longitudinal study. Computers Human Behavior. 2013;29:1102-1112

28. Koohikamali M, Peak DA, Prybutok VR. Beyond self-disclosure: disclosure of information about others in social network sites. Computers Human Behavior. 2017;69:29-42

29. Pereira S, Robinson J0, Peoples HA, et al. Do privacy and security regulations need a status update? Perspectives from an intergenerational survey. PLoS One. 2017;12(9):e0184525

30. Christakis NA, Fowler JH. Social contagion therapy: examining dynamic social networks and human behavior. Stat Med. 2013; 32(4):556-577

31. Alshamsi A, Pianesi F, Lepri B, Pentland A, Rahwan I. Beyond contagion: reality mining reveals complex patterns of social influence. PLoS One. 2015;10(8):e0135740 
32. Langenfeld SJ, Vargo DJ, Schenarts PJ. Balancing privacy and professionalism: a survey of general surgery program directors on social media and surgical education. J Surg Educ. 2016;73(6):e28-e32

33. Gomes AW, Butera G, Chretien KC, Kind T. The development and impact of a social media and professionalism course for medical students. Teach Learn Med. 2017;29(3):296-303

34. Flickinger TE, Hagan T, Chisolm MS. Developing a curriculum to promote professionalism for medical students using social media: pilot of a workshop and blog-based intervention. JMIR Med Educ. 2015:1(2):e17

35. Applebaum PS, Gutheil TG. Confidentiality and Privilege. In: Applebaum PS, Gutheil TG , editors. Clinical Handbook of Psychiatry and the Law, Fourth Ed. Philadelphia, PA: Lippincott Wilkins \& Williams; 2007. pp. 1-34 
medRxiv preprint doi: https://doi.org/10.1101/2020.03.05.20031526; this version posted March 6, 2020. The copyright holder for this preprint (which was not certified by peer review) is the author/funder, who has granted medRxiv a license to display the preprint in perpetuity. All rights reserved. No reuse allowed without permission.

Table 1. Characteristics of 656 doctors and healthcare providers sharing 754 tweets disclosing information about others

\begin{tabular}{|c|c|c|c|}
\hline Participants & No. & $\%$ & $\%$ of subgroup \\
\hline \multicolumn{4}{|l|}{ Gender } \\
\hline \begin{tabular}{|l|} 
Female \\
\end{tabular} & 384 & $58.5 \%$ & \\
\hline Male & 266 & $40.5 \%$ & \\
\hline Unknown & 6 & $0.9 \%$ & \\
\hline \multicolumn{4}{|l|}{ Profession } \\
\hline \begin{tabular}{l|l} 
Doctor \\
\end{tabular} & 486 & $74.1 \%$ & \\
\hline Anesthesia & 22 & & $4.5 \%$ \\
\hline Cardiology & 25 & & $5.1 \%$ \\
\hline Critical Care & 12 & & $2.5 \%$ \\
\hline Emergency Medicine & 77 & & $15.8 \%$ \\
\hline $\begin{array}{l}\text { Family Medicine- } \\
\text { General Practitioner }\end{array}$ & 48 & & $9.9 \%$ \\
\hline Gastroenterology & 6 & & $1.2 \%$ \\
\hline Hematology-Oncology & 39 & & $8.0 \%$ \\
\hline Hospitalist & 5 & & $1.0 \%$ \\
\hline Infectious Disease & 5 & & $1.0 \%$ \\
\hline Internal Medicine & 12 & & $2.5 \%$ \\
\hline Neurosurgery & 5 & & $1.0 \%$ \\
\hline OB/GYN & 13 & & $2.7 \%$ \\
\hline Palliative Care & 18 & & $3.7 \%$ \\
\hline Pathology & 9 & & $1.9 \%$ \\
\hline Pediatrics & 28 & & $5.8 \%$ \\
\hline Psychiatry & 7 & & $1.4 \%$ \\
\hline Pulmonary Medicine & 7 & & $1.4 \%$ \\
\hline $\begin{array}{l}\text { Radiation } \\
\text { Oncology/Clinical } \\
\text { Oncology }\end{array}$ & 10 & & $2.1 \%$ \\
\hline Radiology & 6 & & $1.2 \%$ \\
\hline Surgery & 19 & & $3.9 \%$ \\
\hline Trauma Surgery & 20 & & $4.1 \%$ \\
\hline Unknown & 36 & & $7.4 \%$ \\
\hline Other & 57 & & $11.7 \%$ \\
\hline Nurse & 98 & $14.9 \%$ & \\
\hline \begin{tabular}{l|l} 
& Nurse, NOS
\end{tabular} & 66 & & $67.3 \%$ \\
\hline Critical Care & 16 & & $16.3 \%$ \\
\hline Emergency Medicine & 8 & & $8.2 \%$ \\
\hline Other & 8 & & $8.2 \%$ \\
\hline Nurse Practitioner & 12 & $1.8 \%$ & \\
\hline Paramedic & 18 & $2.7 \%$ & \\
\hline Pharmacist & 7 & $1.1 \%$ & \\
\hline Physical Therapy & 10 & $1.5 \%$ & \\
\hline Psychologist & 5 & $0.8 \%$ & \\
\hline
\end{tabular}


medRxiv preprint doi: https://doi.org/10.1101/2020.03.05.20031526; this version posted March 6, 2020. The copyright holder for this preprint (which was not certified by peer review) is the author/funder, who has granted medRxiv a license to display the preprint in perpetuity. All rights reserved. No reuse allowed without permission.

\begin{tabular}{|l|l|c|c|c|}
\hline & Social Worker & 7 & $1.1 \%$ & \\
\hline & Speech Therapy & 5 & $0.8 \%$ & \\
\hline & Other & 8 & $1.2 \%$ & \\
\hline \multicolumn{1}{|l|}{ Country } & & & \\
\hline & Australia & 11 & $1.7 \%$ & \\
\hline & Canada & 99 & $15.1 \%$ & \\
\hline & India & 7 & $1.1 \%$ & \\
\hline & Ireland & 16 & $2.4 \%$ & \\
\hline & Saudi Arabia & 7 & $1.1 \%$ & \\
\hline & South Africa & 4 & $0.6 \%$ & \\
\hline & Spain & 4 & $0.6 \%$ & \\
\hline & United Kingdom & 82 & $12.5 \%$ & \\
\hline & United States & 347 & $52.9 \%$ & \\
\hline & Unknown & 55 & $8.3 \%$ & \\
\hline & Other & 24 & $3.7 \%$ & \\
\hline
\end{tabular}


Table 2. Content Characteristics of 754 Tweets with Disclosures about Others

\begin{tabular}{|c|c|c|}
\hline & No. (\%) & $\%$ \\
\hline \multicolumn{3}{|l|}{ Author Role } \\
\hline \begin{tabular}{l|l} 
Healthcare Professional \\
\end{tabular} & 669 & $88.7 \%$ \\
\hline Patient & 0 & \\
\hline Caregiver & 42 & \\
\hline Other & 43 & \\
\hline \multicolumn{3}{|l|}{ Time Frame Described } \\
\hline Within past year & 5 & $0.7 \%$ \\
\hline $1-2$ years & 6 & $0.8 \%$ \\
\hline $2-5$ years & 5 & $0.7 \%$ \\
\hline$>5$ years & 79 & $10.5 \%$ \\
\hline Unknown/Not Described & 659 & $87.4 \%$ \\
\hline \multicolumn{3}{|l|}{ Content } \\
\hline Author involved in patient care & 635 & $84.2 \%$ \\
\hline Actively dying patient or patient death & 337 & $44.7 \%$ \\
\hline Saving a patient's life & 131 & $17.4 \%$ \\
\hline Include a clinical image & 11 & $1.5 \%$ \\
\hline Include patient name & 15 & $2.0 \%$ \\
\hline Provide specific patient age & 163 & $21.6 \%$ \\
\hline Express negative opinion of patient or family & 4 & $0.5 \%$ \\
\hline Mention medical error & 6 & $0.8 \%$ \\
\hline \multicolumn{3}{|l|}{ Estimated Likely ("more likely than not") } \\
\hline $\begin{array}{l}\text { Can family or friends identify situation } \\
\text { described? }\end{array}$ & 242 & $32.1 \%$ \\
\hline Can patient identify situation described? & & \\
\hline All tweets & 183 & $24.3 \%$ \\
\hline Potentially living patients (348 tweets) & 162 & $46.6 \%$ \\
\hline Vulnerable population & 152 & $20.2 \%$ \\
\hline
\end{tabular}


medRxiv preprint doi: https://doi.org/10.1101/2020.03.05.20031526; this version posted March 6, 2020. The copyright holder for this preprint (which was not certified by peer review) is the author/funder, who has granted medRxiv a license to display the preprint in perpetuity. All rights reserved. No reuse allowed without permission.

Figure 1. Tweets by doctors and other health care providers (HCP) during \#ShareAStoryInOneTweet in May 2018.

Figure 2. Tweets per hour including the hashtag \#ShareAStoryInOneTweet, May 2018. 
Figure 1. Tweets by doctors and other health care providers (HCP) during \#ShareAStoryInOneTweet in May 2018

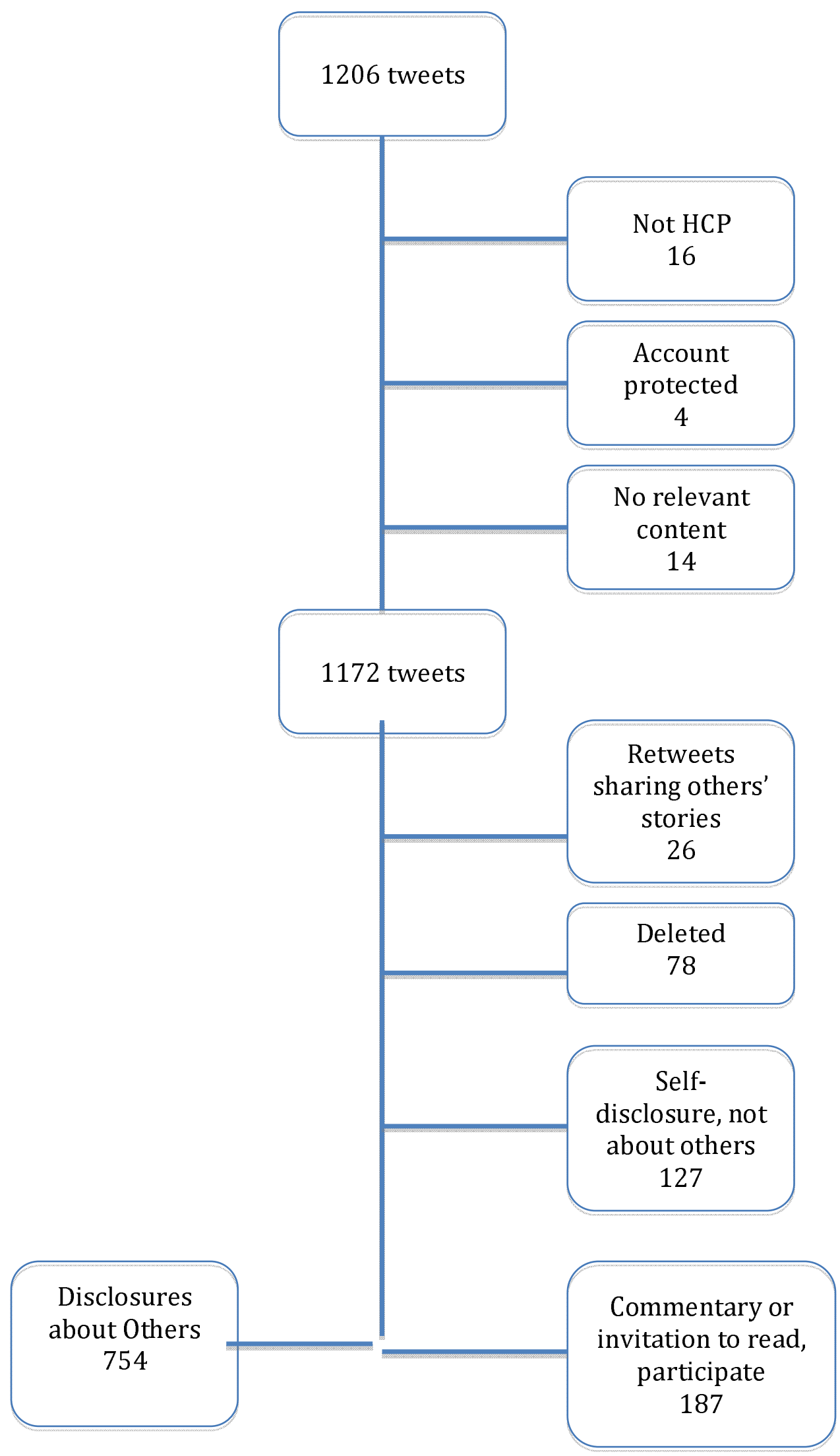


Figure 2. Tweets per hour including the hashtag \#ShareAStoryInOneTweet, May 2018.

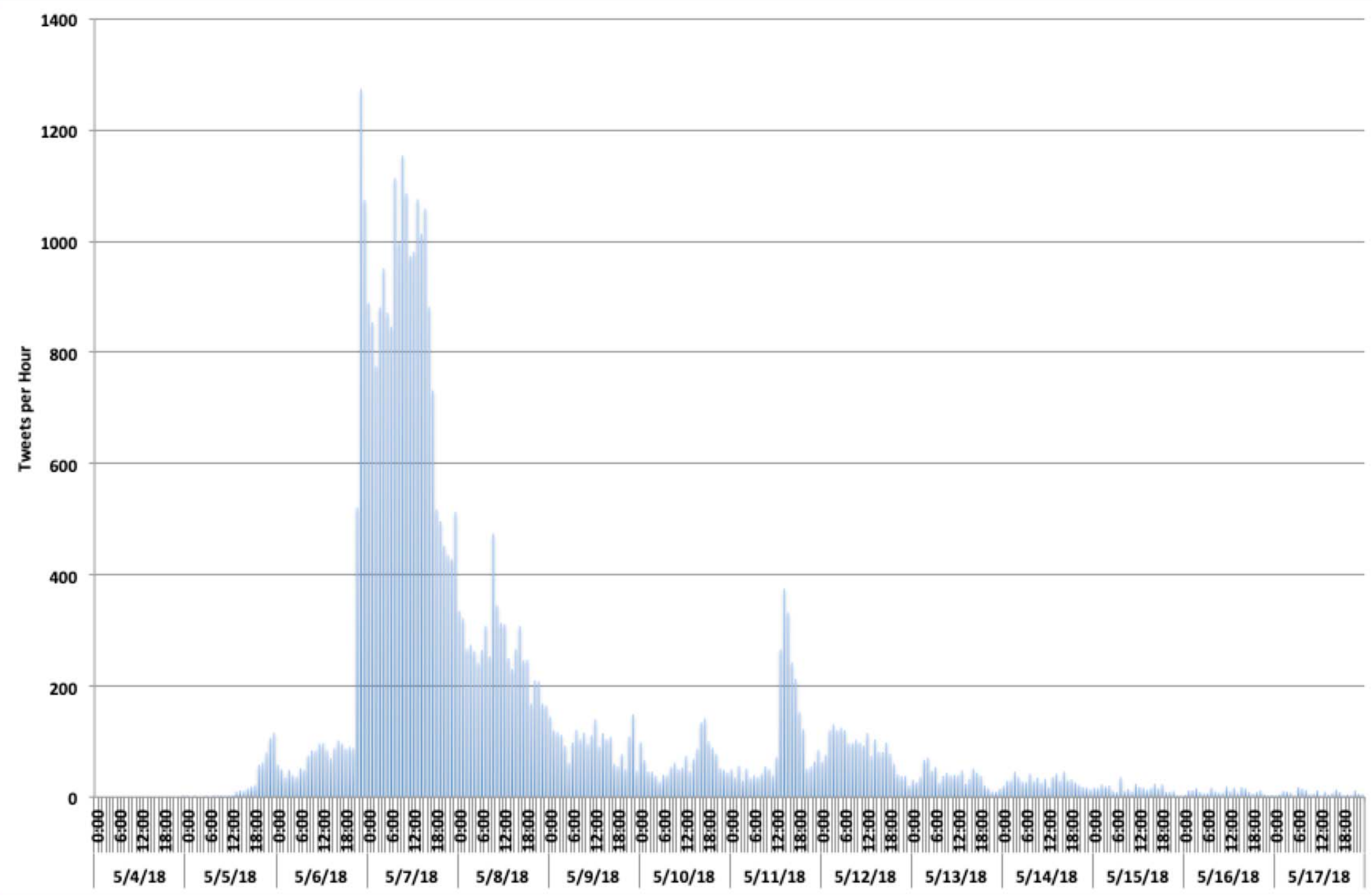




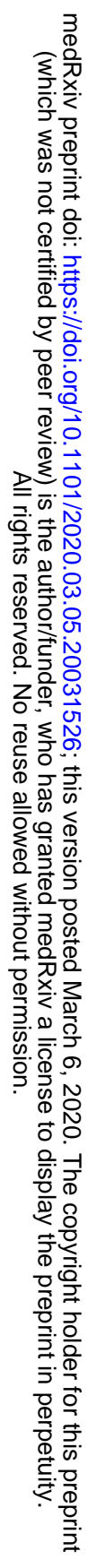




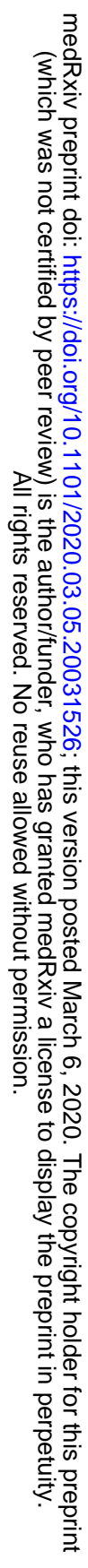

